\title{
MELIMEX, an experimental heavy metal pollution study: Goals, experimental design and major findings
}

\author{
By René Gächter \\ Swiss Federal Institute for Water Resources and Water Pollution Control (EAWAG) at Swiss Federal \\ Institutes of Technology (ETH)
}

Manuscript received on 28 June 1979

\begin{abstract}
It was the goal of the interdisciplinary research project MELIMEX to study ecological consequences of increased heavy metal loadings on limnic ecosystems. A detailed description of the limno-corrals (diameter $12 \mathrm{~m}$, depth $10 \mathrm{~m}$, water flow through rate $11.5 \mathrm{~m}^{3} /$ day) used in this study is presented. Since the physico-chemical environment must have a direct bearing on the results of such an experiment a brief description of Lake Baldegg, in which the experiments were conducted is given and conditions in which limno-corrals differ from natural systems are discussed. Furthermore the major findings of the various MELIMEX studies are briefly summarized.
\end{abstract}

Elevated metal concentrations in recent sediments strongly indicate that during recent decades, heavy metal pollution of aquatic systems has increased practically all over the world. In spite of this, only a few cases of obviously adverse perturbations of aquatic populations have been reported. Nevertheless, it would be incorrect to conclude from this, that the widespread heavy metal pollution will be without effect on aquatic organisms. It must rather be assumed that changes in these ecosystems have not been able to be detected for lack of comparable unpolluted control systems or that they could not be related to increased heavy metal loadings because contamination with other substances changed simultaneously.

Most of the available information regarding the consequences of heavy metal pollution for aquatic organisms stems from experiments investigating short-term effects of increased heavy metal concentrations, or from a few field observations made at extremely heavily loaded sites. Although such investigations provide very valuable information about acute toxicity it must be kept in mind, that long-term exposure at much lower concentrations may eliminate sensitive species and thus cause major shifts in species composition. Due to interspecific relationships (e.g. competition for nutrient or predator-prey interactions, etc.) also heavy metal tolerant species might become negatively affected or even be eliminated. On the other hand a given population may strongly react in a short-term experiment but adapt metabolically during long-term exposure, so that finally no obvious effects can 
be detected anymore. Thus, based on the available information, it is extremely difficult, if not impossible, to predict ecological consequences of a continuously increased heavy metal discharge to a lake, especially if simultaneous interactions of different metals have to be considered.

For this reason, analogous to the marine CEPEX [4] experiment, a long-term experiment, called MELIMEX (MEtal LIMnological EXperiment), was initiated

- to study how the heavy metal concentrations legally tolerated for rivers (see table 2) would affect phytoplankton [5], zooplankton [13], bacteria [3] and bottom fauna $[10]$ of a receiving lake;

- to study accumulation and distribution of $\mathrm{Hg}, \mathrm{Cu}, \mathrm{Cd}, \mathrm{Zn}$ and $\mathrm{Pb}$ in different compartments of a natural food web [6];

- to investigate mechanisms which contribute to sedimentation and redissolution of different metals at the sediment-water interface [1,7];

- to investigate, if increased heavy metal concentrations would affect either production or decomposition of dissolved organic ligands and thus would alter speciation and physiological availability of heavy metals $[2,5,11]$.

The selected technique to study the effect of increased heavy metal loading on a natural pelagic community was to isolate part of the environment using large cylinders and to simulate inflow and outflow by pumping water into and out of the enclosures. Since the biological response might vary seasonnally (different species, temperature and light conditions, different nutrient concentrations) the experiment covered more than one annual cycle. During this period, due to periphyton growth, every clear foil becomes intransparent. For this reason and because rubber is more resistant to mechanical damage, it was decided to construct limno-corrals from rubber foil (DAGTAN-80 Dätwiler, Altdorf, Switzerland), as suggested by Lack [9]. Figure 1 shows the principle of construction. The limno-corrals were $12 \mathrm{~m}$ in diameter and $12.5 \mathrm{~m}$ in length. Heavy chains were inserted into sleeves at their bases

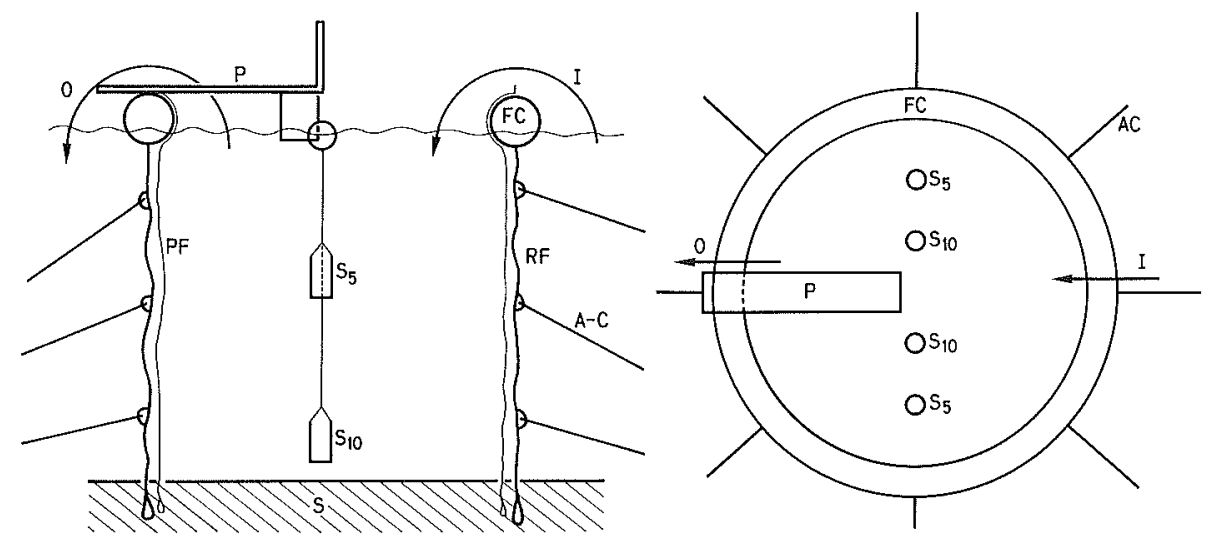

Figure 1. Diagram of limno-corral. $I=$ inflow, $\mathrm{O}=$ outflow, $\mathrm{P}=$ sampling-platform, $\mathrm{RF}=$ rubber foil, $\mathrm{S}_{5}$ and $\mathrm{S}_{10}=$ sedimentation trap in 5 and $10 \mathrm{~m}$, respectively, $\mathrm{S}=$ sediment, $\mathrm{PF}=$ polyethylene foil, $\mathrm{FC}=$ floating collar, A-C = anchor-cable.

Abb. 1. Schematische Darstellung der Versuchsbehälter. $\mathrm{I}=\mathrm{Zufluss,} \mathrm{O}=$ Abfluss, $\mathrm{P}=$ Probenahmesteg, $R F=$ Gummifolie, $S_{5}$ und $S_{10}=$ Sedimentformen in 5 und $10 \mathrm{~m}$ Tiefe, $S=$ Sediment, $\mathrm{PF}=$ Polyäthylenfolie, $\mathrm{FC}=$ Schwimmkörper, $\mathrm{A}-\mathrm{C}=$ Ankerleinen. 
to sink them into the mud. Rings, made from iron tubes, inserted in three seams kept them in circular shape. The floating collar (FC) was filled with plastic bags containing small styrofoam balls. In order to collect sedimentating particles, sedimentation traps $\left(S_{5}\right.$ and $\left.S_{10}\right)$ were exposed in each tube 5 and $10 \mathrm{~m}$ below lake surface. A wooden floating platform (P) allowed easy sampling in the center of the tubes.

Since it was found that the rubber foil (RF) used for construction released some zinc, a polyethylene foil (PF) was inserted in order to separate the enclosed water from the rubber foil. This polyethylene foil neither sorbed nor released $\mathrm{Zn}, \mathrm{Cu}, \mathrm{Hg}$, $\mathrm{Cd}$ or $\mathrm{Pb}$ but nevertheless, as demonstrated by Baccini [1] it could not completely prevent zinc contamination of the enclosed water.

The corrals were installed at the northern end of Lake of Baldegg at a site, where water depth reached about $10 \mathrm{~m}$ (see fig. $2 \mathrm{~b}$ ). Thus the volume of enclosed water equaled about $1,130 \mathrm{~m}^{3}$.

Lake of Baldegg is a highly eutrophic lake located in the central part of Switzerland. Typical values for phosphorus loading, primary production and average transparency during summer stagnation period are $2.5 \mathrm{~g} \mathrm{P} / \mathrm{m}^{2} \mathrm{yr}, 420 \mathrm{~g} \mathrm{C} / \mathrm{m}^{2} \mathrm{yr}$ and $1.2 \mathrm{~m}$, respectively. In extreme situations, oxygen is detectable only in the top $5 \mathrm{~m}$; below $15 \mathrm{~m} \mathrm{H}_{2} \mathrm{~S}$ can regularly be observed with maximum values of 5 to $6 \mathrm{mg} / \mathrm{l}$ at the lake bottom. Some further data concerning the lake's morphometry, hydrography and chemistry are compiled in table 1.

Table 1. Data on morphometry and hydrography and chemistry of Lake Baldegg.

Tabelle 1. Einige Daten über Morphometrie, Hydrographie und Chemismus des Baldeggersees.

\begin{tabular}{|c|c|c|}
\hline Lake surface area & $5.3 \mathrm{~km}^{2}$ & Seeoberfläche \\
\hline Maximun depth & $66 \mathrm{~m}$ & Maximale Tiefe \\
\hline Mean depth & $34 \mathrm{~m}$ & Mittlere Tiefe \\
\hline Area of drainage bassin & $74.2 \mathrm{~km}^{2}$ & Fläche des Einzugsgebiets \\
\hline Average flow rate & $1 \mathrm{~m}^{3} / \mathrm{sec}$ & Mittlere Abflussrate \\
\hline $\begin{array}{l}\text { Phosphorus concentration } \\
\text { at spring overturn }\end{array}$ & $400 \mathrm{mg} / \mathrm{m}^{3}$ & $\begin{array}{l}\text { Phosphorkonzentration bei } \\
\text { Vollzirkulation }\end{array}$ \\
\hline $\begin{array}{l}\text { Average DOC concentration } \\
\text { in the epilimnion }\end{array}$ & $4 \mathrm{mg} / \mathrm{l}$ & $\begin{array}{l}\text { Mittlere DOC-Konzentration } \\
\text { im Epilimnion }\end{array}$ \\
\hline $\begin{array}{l}\text { Average Ca concentration } \\
\text { in the epilimnion }\end{array}$ & 3 milliequivalent $/ 1$ & $\begin{array}{l}\text { Mittlere Ca-Konzentration im } \\
\text { Epilimnion }\end{array}$ \\
\hline $\begin{array}{l}\text { Average alkalinity in } \\
\text { the epilimnion }\end{array}$ & 3 milliequivalent/l & Mittlere Alkalinität im Epilimnion \\
\hline $\begin{array}{l}\text { Range of } \mathrm{pH} \text { in the } \\
\text { epilimnion }\end{array}$ & 7.5 to 9.6 & pH-Bereich im Epilimnion \\
\hline
\end{tabular}

The limno-corrals were installed on 20 November 1976. For reasons mentioned below, it was expected, and was later confirmed by the CEPEX experiment (Thomas et al. [12]), that in an initial phase the crop levels would most likely decrease, and that species composition in the corrals would change in comparison to the lake. Thus the enclosed plankton was allowed to adapt to new environmental conditions within the enclosures and to establish a new equilibrium before the experiment with increased heavy metal loading of limno-corrals L1 and L2 was started on 4 April 1977. 
Table 2. Maximum legally tolerated concentrations for different heavy metals in Swiss running waters. Average concentrations in the inflows to limno-corral $\mathrm{C}$ (control) and the heavy metal loaded limnocorrals L1 and L2. Numbers indicate $10^{-8}$ mole $/ 1$, n.d. $=$ not detectable.

Tabelle 2. Schwermetallkonzentrationen, die im Filtrat von Fliessgewässern $(0,45 \mu \mathrm{m})$ gesetzlich toleriert werden, sowie mittlere Konzentrationen im Zulauf zu den Behältern C, L1 und L2. Angaben $10^{-8} \mathrm{Mol} / 1$, n.d. $=$ nicht nachweisbar.

\begin{tabular}{|c|c|c|c|c|c|}
\hline & $\mathrm{Hg}$ & $\mathrm{Cu}$ & $\mathrm{Cd}$ & $\mathrm{Zn}$ & $\mathrm{Pb}$ \\
\hline $\begin{array}{l}\text { Tolerated concentrations } \\
\text { in Swiss running waters } \\
\text { Gesetzlich tolerierte } \\
\text { Konzentrationen }\end{array}$ & 0.5 & 16 & 4.5 & 308 & 24 \\
\hline $\begin{array}{l}\text { Average inflow concentrations } \\
\text { on limno-corral C } \\
\text { Zuflusskonzentration zu C }\end{array}$ & n.d. & 2 & 0.06 & 10 & 0.1 \\
\hline $\begin{array}{l}\text { Average inflow concentrations } \\
\text { of limno-corral } \mathrm{L} 1 \text { and } \mathrm{L} 2 \\
\text { Zuflusskonzentration } \mathrm{zu} \mathrm{L1} \text { und L2 }\end{array}$ & 0.5 & 18 & 4.5 & 320 & 24 \\
\hline
\end{tabular}

As shown in figure $2 \mathrm{a}$, a system of four pumps was used to pump water into and out of the limno-corrals and thus to simulate inflow and outflow of a lake. The inflowing water was taken near the lake surface and, after filtration through a $54 \mu \mathrm{m}$ net to

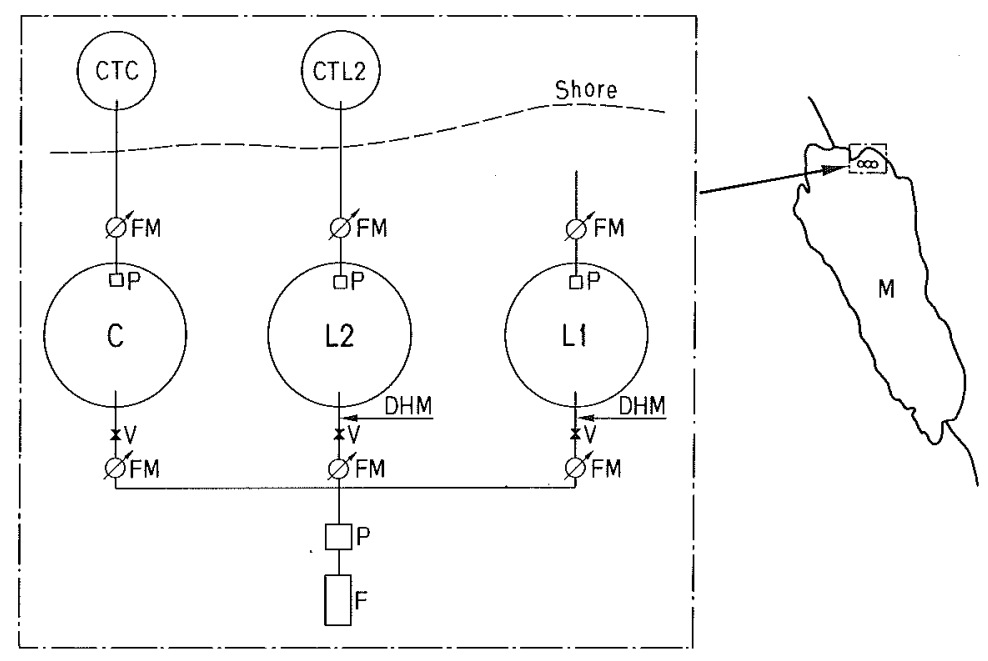

Figure 2. a) Scheme of pumping and metal dosing system. CTC and CTL2 = circular troughs, $\mathrm{FM}=$ flow meter, $\mathrm{P}=$ pump, $\mathrm{C}=$ control, $\mathrm{L} 1$ and $\mathrm{L} 2=$ metal loaded limno-corrals, $\mathrm{HMD}=$ dosage of heavy metal solution, $\mathrm{V}=$ valve, $\mathrm{F}=$ filter.

b) Experimental site and mid-lake station (M).

Abb.2. a) Pumpen und Dosiersystem. CTC und CTL2 $=$ Rundtröge, FM = Durchflussmesser, $\mathrm{P}=$ Pumpe, $\mathrm{C}=$ Kontrolle, $\mathrm{L} 1$ und $\mathrm{L} 2=$ metallbelastete Behälter, HMD $=$ Dosierung von Schwermetallösung, $\mathrm{V}=$ Ventil, $\mathrm{F}=$ Filter.

b) Grundriss des Baldeggersees mit eingezeichnetem Versuchsfeld und der Probenahmestation in der Seemitte (M). 
remove larger phyto- and zooplankton organisms, distributed to the three limnocorrals. Whereas metal concentrations of the inflow to the control (C) were identical to ambient concentrations of the lake, dosage of a highly concentrated inorganic metal solution increased the metal concentration in the inflows of the two metal loaded corrals ( $\mathrm{L} 1$ and L2) to the values listed in table 2. Between 29 July 1977 and 22 August 1977 the automatic dosage system did not work properly. As a result as indicated in table 3, the heavy metal concentrations of the inflows to L1 and L2 exceeded the legally maximum tolerated limits during this period. The unfiltered outflows were either pumped back into the lake or, as in the case of C and L2 into the circular troughs CTC and CTL2 in which fish fry (bream and trout) were kept. As shown in figure $2 \mathrm{a}$ inflows and outflows were measured with flow meters connected to the pipes. All pumps were started automatically in 3-hour intervals. Inflows and outflows were stopped when $2 \mathrm{~m}^{3}$ had passed the corresponding flowmeter. Working time of the pumping system varied between 2.5 and 3 hours. Thus, provided it was working properly, inflow and outflow pumps worked nearly continuously, and the automatic controlling system ensured that within a 3-hour period inflow always equaled outflow. If one pump did not reach $2 \mathrm{~m}^{3}$ within the present 3-hour interval, the entire pumping system was blocked automatically and had to be restarted manually after elimination of the defect.

Table 3. Metal concentration in inflows to limno-corrals L1 and L2 during the period 29 July 1977 to 22 August 1977 (figures indicate $10^{-8} \mathrm{~mole} / \mathrm{l}$ ).

Tabelle 3. Metallkonzentration im Zuffuss zu den Behältern L1 und L2 im Zeitabschnitt 29. Juli 1977 bis 22. August 1977 (Angaben in 10-8 $\mathrm{Mol} / 1$ ).

\begin{tabular}{lllllll}
\hline Period & Flow $\left(\mathrm{m}^{3}\right)$ & & & & \\
Periode & Durchfluss & $\mathrm{Hg}$ & $\mathrm{Cu}$ & $\mathrm{Cd}$ & $\mathrm{Zn}$ & $\mathrm{Pb}$ \\
\hline 29.7.- 4.8. & 94 & 0.63 & 19 & 5.3 & 366 & 29 \\
4.8.- 5.8. & 24 & 0.70 & 21 & 5.8 & 403 & 32 \\
5.8.- 8.8. & 62 & 0.55 & 16 & 4.6 & 318 & 25 \\
8.8.-10.8. & 30 & 0.84 & 25 & 7.1 & 489 & 39 \\
$10.8 .-18.8$. & 82 & 0.93 & 28 & 7.8 & 537 & 42 \\
$18.8 .-22.8$. & 40 & 1.06 & 32 & 8.9 & 615 & 48 \\
\hline
\end{tabular}

The average hydraulic loading throughout the whole experiment yielded $11.5 \mathrm{~m}^{3} /$ day. Thus the mean refilling time of the limno-corrals was in the order of 100 days. Although this renewal rate is relatively high, it is not uncommon for shallow lakes. Furthermore, the sediment-area/water-volume ratio of the model lakes corresponds to natural lakes with a mean depth of $10 \mathrm{~m}$. Nevertheless, conditions in limno-corrals differ in many respects from natural systems due to

- the presence of vertical enclosure walls,

- their limited horizontal dimension, and

- the wind and wave shielding effect of the floating collars.

Vertical enclosure walls increase the area for periphyton growth, and due to shading, diminish phytoplankton production. Thus in artificial enclosures, effects of periphyton on their metal metabolism most probably will exceed the effects to be 
expected in natural lakes. On the other hand, for reasons discussed below, effects caused by phytoplankton might be underestimated, when extrapolating directly to natural systems. Physical separation of a water column will decrease its nutrient loading, and, as shown by Imboden et al. [8], decrease turbulent mixing, resulting in a somewhat more shallow epilimnion compared to the open lake. As a result, enclosing a water column will cause a decrease in phytoplankton primary production and may increase sedimentation rates.

Thus, it must be realized that in spite of the intention to simulate natural conditions as closely as possible, not all results obtained in this study can be transferred quantitatively to conditions of natural lakes. Nevertheless, the MELIMEX study yielded some important results which should be considered, when ecological effects and chemical behaviour of heavy metals in lake ecosystems are discussed. The major findings may be summarized as follows:

1. Increasing the heavy metal load of lakes up to the actually legally tolerated limits (see table 2) adversely affects its phytoplankton, zooplankton and bottom fauna [5, $10,13]$. It causes major shifts in phytoplankton community towards more metal resistant species which take up less metal per unit of biomass $[5,6]$.

2. Although increasing the metal load of a lake in general causes an increase of its organisms metal content, inorganic copper, mercury, cadmium, zinc and lead are not biomagnified in the food chain as was observed, e.g. for chlorinated hydrocarbons [6]. Fish fry seem to be able to control its copper and zinc content and to maintain it on a constant level, regardless of environmental concentrations.

3. Depending on their chemical nature, $\mathrm{Hg}, \mathrm{Cu}, \mathrm{Cd}, \mathrm{Zn}$ and $\mathrm{Pb}$ become eliminated at different rates from an aquatic ecosystem [1]. It is concluded that in lakes, uptake by phytoplankton is the main sink for dissolved heavy metal salts; at the metal concentrations under discussion, inorganic precipitation is unimportant. Thus, concentrations of dissolved metals depend not only on the external metal loading of a lake but also are strongly affected by its trophic state.

4. Increased metal concentrations not only affect a lake's biota, but as an indirect result also may cause changes in its spectrum of dissolved organic compounds $[5$, 11]. Such changes influence metal speciation [5] but the question, if they also would influence the availability of metals to aquatic organisms, could not yet be answered unequivocally $[2,5]$.

\section{ZUSAMMENFASSUNG}

Gemäss der Verordnung über Abwassereinleitungen dürfen in Fliessgewässern die in Tabelle 2 zusammengestellten Metallkonzentrationen nicht überschritten werden. Es war das Ziel der MELIMEXStudie (= MEtall-LIMnologisches EXperiment), die Auswirkungen dieser Metallkonzentrationen auf Organismen in tiefer liegenden Seen zu untersuchen.

$\mathrm{Zu}$ diesem Zweck wurden am 14. November $1976 \mathrm{im}$ Baldeggersee (siehe Abb.2, Tab. 1), einem stark eutrophen See der Zentralschweiz, drei Wasserkörper von $12 \mathrm{~m}$ Durchmesser und $10 \mathrm{~m}$ Tiefe vom übrigen See abgetrennt, ohne die Wechselwirkungen zwischen Sediment und Wasser zu beeinflussen. Vom 4. April 1977 bis Ende Juni 1978 wurden die $\mathrm{Hg}$-, Cu-, Cd-, Zn- und Pb-Konzentrationen im Zulauf zu den Behältern L1 und L2 (metallbelastete Behälter) auf die in Tabelle 2 angegebenen Werte erhöht. Die Kontrolle (C) wurde mit grob filtriertem $(54 \mu \mathrm{m})$, in seiner chemischen Beschaffenheit aber unverändertem Baldeggerseewasser gespiesen (siehe Abb.2). Der Abfluss aus den Behältern wurde 
entweder in den See oder in am Ufer aufgestellte Rundtröge (CTC und CTL2) geleitet, in welchen Brut von Brachsen (Abramis brama) und Seeforellen (Trutta fario $\mathrm{f}$. lacustis) gehalten wurden. Die mittlere hydraulische Belastung der in Abb. 1 schematisch dargestellten Versuchsbehälter betrug $11,6 \mathrm{~m}^{3} / \mathrm{Tag}$, woraus eine mittlere Aufenthaltszeit des Wassers von etwa 100 Tagen resultiert.

Die wichtigsten Resultate der Studie lassen sie wie folgt zusammenfassen:

1. Durch die erhöhten SM-Konzentrationen wurden sowohl das Phytoplankton, das Zooplankton als auch die Bodenfauna negativ beeinflusst $[5,10,13]$. Sie verursachen qualitative und quantitative Veränderungen in der Zusammensetzung des Phytoplanktons, wobei sich die resultierenden Populationen in der Regel durch eine erhöhte Metallresistenz [5] und durch eine verringerte Metallsorptionskapazität [6] auszeichneten.

2. Die erhöhten Metallkonzentrationen im Medium führten zwar zu erhöhten Metallgehalten im Plankton [6], aber es ergaben sich keinerlei Anzeichen für eine Anreicherung der Metalle in der Nahrungskette. In bezug auf die Trockensubstanz waren die Metallkonzentrationen im Phytoplankton und Periphyton deutlich höher als im Zooplankton oder in der Fischbrut. Jungfische von Brachsen und Seeforellen scheinen in der Lage zu sein, ihren Kupfer- und Zinkgehalt unabhängig von der Umgebungskonzentration auf einem konstanten Niveau halten zu können.

3. $\mathrm{Hg}, \mathrm{Cu}, \mathrm{Cd}, \mathrm{Zn}$ und $\mathrm{Pb}$ werden entsprechend ihrer unterschiedlichen chemischen Natur unterschiedlich rasch aus aquatischen Ökosystemen eliminiert [1]. Es zeigt sich, dass das Phytoplankton die hauptsächlichste Senke für gelöste SM darstellt und dass anorganische Fällungen bei den vorliegenden Konzentrationen keine wesentliche Rolle spielen.

4. Erhöhte SM-Konzentrationen beeinflussen nicht nur die Organismen eines Sees, sondern verursachen indirekt auch Verschicbungen im Spektrum von gelösten organischen Verbindungen [5, 11]. Die Frage, inwieweit dadurch auch die physiologische Verfügbarkeit der Metalle für Organismen verändert wurde, kann aufgrund der vorliegenden Information jedoch noch nicht schlüssig beantwortet werden.

\section{RÉSUMÉ}

Selon l'ordonnance sur l'introduction des eaux usées dans les eaux courantes, les concentrations de métaux, réunis dans le tableau 2, ne doivent pas être dépassées. Le but des études du MELIMEX (= MEtall-LIMnologisches EXperiment) fut d'étudier les effets de ces concentrations sur les organismes dans les lacs.

Dans ce but, on a installé, le 14 novembre 1976, dans le lac de Baldegg, (fig. 2, tabl. 1) un lac très eutrophe de la Suisse centrale, trois bassins cylindriques de $12 \mathrm{~m}$ de diamètre et $10 \mathrm{~m}$ de haut, posé sur le fond, séparés du reste du lac, sans influencer l'effet d'échange entre le sédiment et l'eau. Du 4 avril 1977 jusqu'à la fin juin 1978, les valeurs des concentrations de $\mathrm{Hg}, \mathrm{Cu}, \mathrm{Cd}, \mathrm{Zn}$ et $\mathrm{Pb}$ dans l'affluent des bassins L1 et L2 (chargés de métaux), représentés dans le tableau 2, ont été augmentées. Le bassin de contrôle (C) fut rempli avec l'eau du lac de Baldegg grossièrement filtrée $(54 \mu \mathrm{m})$, mais inchangée dans sa qualité chimique (fig. 2). L'écoulement des bassins fut conduit soit dans le lac, soit dans des bassins circulaires (CTC et CTL2), installés sur la rive, dans lesquels des alevins de truites et de brèmes étaient élevés. La charge hydraulique moyenne qui est représentée schématiquement dans les bassins d'expérience (fig. 1) est de $11,6 \mathrm{~m}^{3} /$ jour, d'où résulte un temps moyen de séjour de l'eau d'environ 100 jours.

Les résultats les plus importants de l'étude se résument comme suit:

1. Les concentrations de métaux lourds ont eu un effet négatif, non seulement sur le phytoplancton, le zooplancton, mais encore sur la faune benthique $[5,10,13]$. Elles provoquent des changements qualitatifs et quantitatifs dans la composition du phytoplancton, d'après quoi les populations qui en résultent se distinguent, dans la règle, par une augmentation de la résistance aux métaux [5] et par une réduction de la capacité d'adsorption des métaux [6].

2. Les concentrations augmentées de métaux dans le milieu conduisaient, il est vrai, à un taux de métal plus élevé dans le plancton [6], mais de ceci, il ne résulte aucun indice d'une augmentation des métaux dans la chaîne alimentaire. En considérant les matières sèches, les concentrations de métaux dans le phytoplancton et le périphyton ont été visiblement plus élevées que dans le zooplancton ou dans les alevins. Les jeunes brèmes et truites du lac semblent être en état de pouvoir maintenir leur teneur en cuivre et en zinc à un niveau constant, indépendamment de la concentration environnante.

3. $\mathrm{Hg}, \mathrm{Cu}, \mathrm{Cd}, \mathrm{Zn}$ et $\mathrm{Pb}$ sont éliminés de l'écosystème aquatique à des vitesses différentes selon leurs différentes natures chimiques [1]. Il semble que le phytoplancton est particulièrement responsable de 
l'élimination des métaux lourds dissouts et que les précipités inorganiques à ces concentrations ne jouent pas de rôle essentiel.

4. Des concentrations augmentées de métaux lourds influencent non seulement les organismes d'un lac, mais encore provoquent indirectement des déplacements dans le spectre des combinaisons organiques dissoutes [5, 11]. Cependant, sur la base de ces informations, on peut pas encore répondre définitivement à la question de savoir jusqu'où la disponibilité physiologique des métaux pour les organismes a été changée.

\section{ACKNOWLEDGMENTS}

Joan Davis critically reviewed this paper and helped very much to clearify it. The figures were drafted by H. Bolliger and A. Widmer typed the manuscript.

\section{REFERENCES}

1 Baccini, P., Ruchti, J., Wanner, O., and Grieder, E.: MELIMEX, an experimental heavy metal pollution study: Regulation of trace metal concentrations in limno-corrals. Schweiz. Z. Hydrol. 4I, 202-227 (1979).

2 Baccini, P., and Sutter, U.: MELIMEX, an experimental heavy metal pollution study: Chemical speciation and biological availability of copper in lake water. Schweiz. Z. Hydrol. 41, 285-308 (1979).

3 Bossard, P.: MELIMEX, an experimental heavy metal pollution study: Effects of increased heavy metal loads on uptake of glucose by natural planktonic communities. Schweiz. Z. Hydrol. 41, 261-270 (1979).

4 CEPEX: Various authors and titles. Bull. mar. Sci. 27, 1-146 (1977).

5 Gächter, R.: MELIMEX, an experimental heavy metal pollution study: Effects of increased heavy metal loads on phytoplankton communities. Schweiz. Z. Hydrol. 41, 228-246 (1979).

6 Gächter, R., and Geiger, W.: MELIMEX, an experimental heavy metal pollution study: Behaviour of heavy metals in an aquatic food chain. Schweiz. Z. Hydrol. 41, 271-284 (1979).

7 Hohl, H.: MELIMEX, an experimental heavy metal pollution study: Particle size distribution in heavy metal loaded and control model lakes. Schweiz. Z. Hydrol. 4I, 190-201 (1979).

8 Imboden, D., Eid, B., Joller, T., Schurter, M., and Wetzel, J.: MELIMEX, an experimental heavy metal pollution study: Vertical mixing in a large limno-corral. Schweiz. Z. Hydrol. 4I,177-189(1979).

9 Lack, T.J., and Lund, J.W.G.: Observations and experiments on the phytoplankton of Belham Tarn. English Lake District. I. The experimental tubes. Freshwat. Biol. 4, 399-415 (1974).

10 Lang, C., and Lang-Dobler, B.: MELIMEX, an experimental heavy metal pollution study: Oligochaetes and chironomid larvae in heavy metal loaded and control limno-corrals. Schweiz. Z. Hydrol. 41, 27I-276 (1979).

11 Leidner, A.: Freie und gebundene, gelöste Aminosäuren in einem mit Schwermetallen belasteten und einem unbelasteten Kontroll-Modellsee. Not published.

12 Thomas, W.H., Holm-Hansen, O., Seibert, D.L.R., Azam, F., Hodson, R., and Takahashi, M.: Effects of copper on phytoplankton standing crop and productivity: CEPEX. Bull. mar. Sci. 27, 3443 (1977).

13 Urech, J.: MELIMEX, an experimental heavy metal pollution study: Effects of increased heavy metal load on crustacea plankton. Schweiz. Z. Hydrol, 41, 247-260 (1979).

Address of the author: Dr. René Gächter, lake research laboratory EAWAG/ETH, CH-6047 Kastanienbaum, Switzerland. 